\title{
Infant weight gain, duration of exclusive breast-feeding and childhood BMI - two similar follow-up cohorts
}

\author{
Ingibjorg Gunnarsdottir ${ }^{1, *}$, Lene Schack-Nielsen², Kim Fleischer Michaelsen², \\ Thorkild IA Sørensen ${ }^{3}$ and Inga Thorsdottir ${ }^{1}$ on behalf of the NordNet Study Group \\ 'Unit for Nutrition Research, Landspitali-University Hospital \& Faculty of Food Science and Nutrition, University \\ of Iceland, Eirikgsgötu 29, 101 Reykjavik, Iceland: ${ }^{2}$ Department of Human Nutrition, Centre of Advanced Food \\ Studies, Faculty of Life Sciences, University of Copenhagen, Bülowsvej 17, 1870 Frederiksberg C, Denmark: \\ ${ }^{3}$ Institute of Preventive Medicine, Copenhagen University Hospital, Centre for Health and Society, Øster Søgade \\ 18, 1357 Copenhagen K, Denmark
}

Submitted 2 September 2008: Accepted 4 March 2009: First published online 17 July 2009

\begin{abstract}
Objective: To describe the association between duration of exclusive breastfeeding (EBF), weight gain in infancy and childhood BMI in two populations with a long duration of EBF.

Design: Cohort study with follow-up in childhood. Breast-feeding status was reported monthly during infancy. Weight and length were measured at birth, 2, 6 and 12 months of age, as well as in childhood at 6 or 10 years of age.

Setting: Iceland and Denmark.

Subjects: Randomly selected healthy newborns from Denmark ( $n 85)$ and Iceland ( $n$ 100).

Results: Infants exclusively breast-fed for $\leq 2$ months gained 348 (95\% CI 69, 626) g more weight from 2 to 6 months than infants exclusively breast-fed for 3-4 months $(P=0 \cdot 009)$. Weight gain from 6 to 12 months was found to be greater among infants exclusively breast-fed for $\leq 2$ months compared with those exclusively breast-fed for $\geq 5$ months $(P=0 \cdot 008)$. A greater weight change, in terms of $Z$-score, between the ages of 2 and 6 months was associated with higher $Z$-score of childhood BMI, adjusted for birth weight, country and duration of EBF $\left(B=0 \cdot 49\right.$, sE $=0 \cdot 11, P<0 \cdot 001$, adj. $\left.R^{2}=0 \cdot 15\right)$. However, the association was much stronger in the Icelandic cohort than the Danish one.

Conclusions: Although duration of EBF was not associated with childhood BMI in the present study it may modulate growth rate in infancy, which is related to childhood BMI. However, other factors determinative for infant growth also need to be considered when assessing the relationship of early growth and nutrition to childhood overweight, as traditions in complementary food might differ between populations.
\end{abstract}

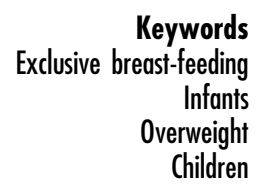

Interest in the early determinants of adult health has increased substantially during the past few years. Development of childhood overweight has in recent studies been related to rapid growth during early life ${ }^{(1-5)}$. Differences in weight gain during early infancy are at least partly explained by the means of feeding. Infant feeding practices vary between regions and countries, and therefore the critical growth periods associated with the development of childhood overweight might vary between different populations. In previous studies on the relationship between infant growth and childhood overweight, either formula feeding was dominating(3) or information on infant feeding patterns was lacking ${ }^{(1,2)}$.

Studies have shown that total duration of breast-feeding is associated with slower growth in the first year of life ${ }^{(6-8)}$, which could contribute to the protective effects of breastfeeding against overweight and obesity ${ }^{(9-11)}$. Breast-feeding is more frequent in the Nordic countries than in many other parts of the world ${ }^{(12,13)}$. In the Nordic Nutrition Recommendations 2004 exclusive breast-feeding (EBF) is recommended up to 6 months of age ${ }^{(14)}$, which is in accordance with WHO recommendations from 2001 onwards ${ }^{(15,16)}$. Previously the recommendation was $4-6$ months. As relatively little is known about the effects of EBF on growth in infancy and its meaning for later childhood BMI, we used existing Danish and Icelandic cohorts that included data on EBF and repeated measurements of growth during infancy, as well as follow-up in childhood, to address this problem.

In the present Nordic collaboration, which is part of the Nordic longitudinal epidemiological research programme, 
we had the opportunity to describe the association between infant weight gain, duration of EBF and childhood BMI. The original infant studies from which the current analysis was conducted were exceptionally detailed ${ }^{(6,17)}$ and of very similar design, giving a possibility to assess periods of infant weight gain in relation to childhood BMI.

\section{Subjects and methods}

\section{Study design}

Both infant studies in Denmark and Iceland included random samples of healthy newborns with almost the same criteria for participation, i.e. singleton birth, birth weight for gestational age between the 10th and 90th percentile, gestational period of $37-41$ or 42 weeks, no neonatal diseases resulting in admission to the neonatal department and no severe malformations, Danish or Icelandic parents, and mothers receiving regular antenatal care $^{(6,17)}$. Both cohorts were followed from birth to 1 year of age by monthly observations, and follow-ups were at 6 and 10 years of age in Iceland and Denmark, respectively. In both studies a control group was recruited at 9 months of age to assess if there were any effects of participating in the study. The Danish study was performed in agreement with the Declaration of Helsinki (1964) and approved by the local ethical committee (Journal no. KF-01-226/97). The local ethical committee at the Landspitali-University Hospital in Iceland and the Icelandic Data Protection Commission approved the study in Iceland.

\section{Coborts}

The sample of infants for the Copenhagen Cohort Study on Infant Nutrition and Growth was recruited from deliveries at Hvidovre Hospital from October 1987 to February $1988^{(17)}$. Hvidovre Hospital is one of the major hospitals in the municipality of Copenhagen, and the participating families were comparable with those in the remaining area. Detailed information on weight gain in infancy was mandatory to the present analysis and available throughout infancy for about eighty-five infants. Information on childhood BMI from follow-up was available for sixty-four subjects ${ }^{(13)}$.

The sample for the Icelandic infant nutrition study ( $n$ 180) was taken during 1995-6 at four different maternity wards around Iceland, distributed by place and date of birth according to Statistics Iceland ${ }^{(6)}$. The criteria set for the follow-up study, i.e. complete data on infant size and growth parameters, along with complete information on breast-feeding throughout infancy, were fulfilled by 100 subjects who were invited to the follow-up study, of whom ninety agreed to participate ${ }^{(12)}$.

\section{Breast-feeding}

Breast-feeding status was reported monthly in both studies. Breast-feeding was defined as exclusive or partial.
EBF allowed supplements of water or camomile tea with no sugar or milk (Denmark), as well as vitamins and minerals (both countries). Infants were classified as partially breast-fed as long as they were breast-fed at least once daily. In the present analysis, the total duration of breastfeeding, calculated as the sum of exclusive and partial breast-feeding, was used. Total duration of breast-feeding was recorded at the age of 12 months. No difference was seen between the control groups and the research groups with respect to breast-feeding and nutrient intake ${ }^{(6,17)}$.

\section{Weight and length/beight measurements in infancy and childbood}

In both cohorts weight and length at birth and throughout infancy were registered. These were used to estimate weight gain and length growth in certain periods in infancy. In the Icelandic study weight was measured to the nearest $0 \cdot 1 \mathrm{~kg}$ (model 1580; Tanita, Tokyo, Japan) and height to the nearest $0.5 \mathrm{~cm}$ at the age of 6 years in a clinical examination at Landspitali-University Hospital. Measurements were used to calculate BMI. In the Copenhagen study height was measured to the nearest $1 \mathrm{~mm}$ using a wall-mounted digital stadiometer (FORCE Institute, Copenhagen, Denmark) and weight was measured to the nearest $0 \cdot 1 \mathrm{~kg}$ using an electronic digital scale (Seca model 707; COMACO A/S, Hammel, Denmark) at the age of 10 years. Subjects wore only underpants and a cotton T-shirt when weighed. BMI was calculated as $\mathrm{kg} / \mathrm{m}^{2}$. No difference was seen between the control groups and the research groups with respect to weight gain during infancy ${ }^{(6,17)}$.

\section{Statistical analysis}

Statistical analyses were performed using the SPSS for Windows statistical software package version 11.0 (SPSS Inc., Chicago, IL, USA). Means and standard deviations were used to describe the data. Comparison of infant weight and length measurements, as well as measures of growth and duration of EBF between countries, was made by the independent-samples $t$ test. ANOVA and the post hoc Bonferoni test were used to assess differences in growth rate in infancy between infants exclusively breastfed for different durations ( $\leq 2$ months, 3-4 months and $\geq 5$ months). Because the follow-up was made at different ages in Iceland and Denmark, age- and gender-specific quartiles were created to assess the impact of infant growth or feeding practices on weight-for-height measures in childhood. Logistic regression models were used to estimate the risk of being in the highest quartile of childhood BMI, using the weight, length and growth variables as continuous. Cut-off points for the highest $25 \%$ for BMI in the age- and gender-specific quartiles were $16 \cdot 44 \mathrm{~kg} / \mathrm{m}^{2}$ in 6-year-old boys, $16 \cdot 39 \mathrm{~kg} / \mathrm{m}^{2}$ in 6-year-old girls, $17 \cdot 87 \mathrm{~kg} / \mathrm{m}^{2}$ in 10 -year-old boys and $17.96 \mathrm{~kg} / \mathrm{m}^{2}$ in 10 -year-old girls. The growth measurements were converted to standard deviation scores taking age and sex into account using the British 1990 growth 
Table 1 Characteristics of the subjects: randomly selected healthy newborns from Denmark and Iceland followed up in childhood

\begin{tabular}{|c|c|c|c|c|c|c|c|}
\hline & \multicolumn{3}{|c|}{ Iceland } & \multicolumn{3}{|c|}{ Denmark } & \multirow[b]{2}{*}{$P$ valuet } \\
\hline & $n$ & Mean & SD & $n$ & Mean & SD & \\
\hline Girls (\%) & \multicolumn{3}{|c|}{$50 \cdot 4$} & \multicolumn{3}{|c|}{$54 \cdot 2$} & \\
\hline \multicolumn{8}{|l|}{ Weight } \\
\hline Birth (g) & 117 & 3846 & 454 & 83 & 3478 & 380 & $<0.001$ \\
\hline Age 2 months (q) & 60 & 5540 & 631 & 86 & 5244 & 588 & 0.004 \\
\hline Age 6 months $(\mathrm{g})$ & 102 & 8075 & 917 & 85 & 7844 & 896 & 0.085 \\
\hline Age 12 months (g) & 76 & 10178 & 984 & 83 & 9885 & 1154 & 0.089 \\
\hline In childhood $\neq(\mathrm{kg})$ & 90 & $23 \cdot 0$ & 3.4 & 64 & $34 \cdot 6$ & $5 \cdot 0$ & \\
\hline \multicolumn{8}{|l|}{ Length } \\
\hline Birth (cm) & 117 & $52 \cdot 5$ & $1 \cdot 9$ & 83 & $52 \cdot 1$ & $2 \cdot 0$ & 0.185 \\
\hline Age 2 months $(\mathrm{cm})$ & 29 & $59 \cdot 3$ & $2 \cdot 0$ & 83 & $58 \cdot 4$ & $2 \cdot 0$ & 0.031 \\
\hline Age 6 months $(\mathrm{cm})$ & 102 & $68 \cdot 5$ & $2 \cdot 2$ & 85 & $67 \cdot 4$ & $2 \cdot 5$ & 0.001 \\
\hline Age 12 months $(\mathrm{cm})$ & 83 & $76 \cdot 8$ & $2 \cdot \overline{5}$ & 83 & $75 \cdot 1$ & $2 \cdot 8$ & $<0.001$ \\
\hline In childhood $\ddagger$ (cm) & 91 & $118 \cdot 9$ & $4 \cdot 3$ & 64 & $142 \cdot 3$ & $5 \cdot 5$ & \\
\hline \multicolumn{8}{|l|}{ Exclusive breast-feeding } \\
\hline Duration (months) & 109 & $3 \cdot 1$ & $1 \cdot 8$ & 86 & $2 \cdot 6$ & $1 \cdot 7$ & 0.034 \\
\hline $0-2$ months (\%) & & 32 & & & 44 & & \\
\hline $3-4$ months $(\%)$ & & 42 & & & 39 & & \\
\hline$\geq 5$ months $(\%)$ & & 26 & & & 18 & & \\
\hline
\end{tabular}

†Significance of the difference between countries using the independent-samples $t$ test.

$\ddagger$ At the age of 6 years in the Icelandic cohort and at the age of 10 years in the Danish cohort.

references ${ }^{(18,19)}$. Linear regression models adjusting for factors such as birth weight, breast-feeding and country were used to assess the association between changes in infant growth patterns and childhood weight and height status. In the statistical analysis the level of significance was taken as $P<0 \cdot 05$.

\section{Results}

\section{Weight and lengtb in infancy}

The weight and length of infants in the Icelandic and Danish cohorts are shown in Table 1. By comparing weight and length growth between Icelandic and Danish infants it can be seen that the average birth weight was 411 (95\% CI 308, 514) g higher in the Icelandic cohort than the Danish $(P<0 \cdot 001)$. Weight gain in the first two months was not significantly different between the two cohorts. The difference in weight seen between the two populations at birth diminished throughout infancy and at 12 months of age the difference in weight between the two cohorts was no longer significant. Birth length was not different between the two cohorts, but at the age of 2 months the Icelandic infants were about $1 \mathrm{~cm}$ longer and this difference persisted throughout infancy.

\section{Infant feeding}

Duration of EBF was on average 0.5 (95\% CI 0.05, 1.0) months longer in Iceland than in Denmark (Table 1). The association between duration of EBF and growth during the first year of life tended to be similar in the countries. Figure 1 shows the birth weight and weight gain in infants exclusively breast-fed for $\leq 2$ months, $3-4$ months and $\geq 5$ months. Higher birth weight was associated with longer duration of EBF, which was attributed to the fact that

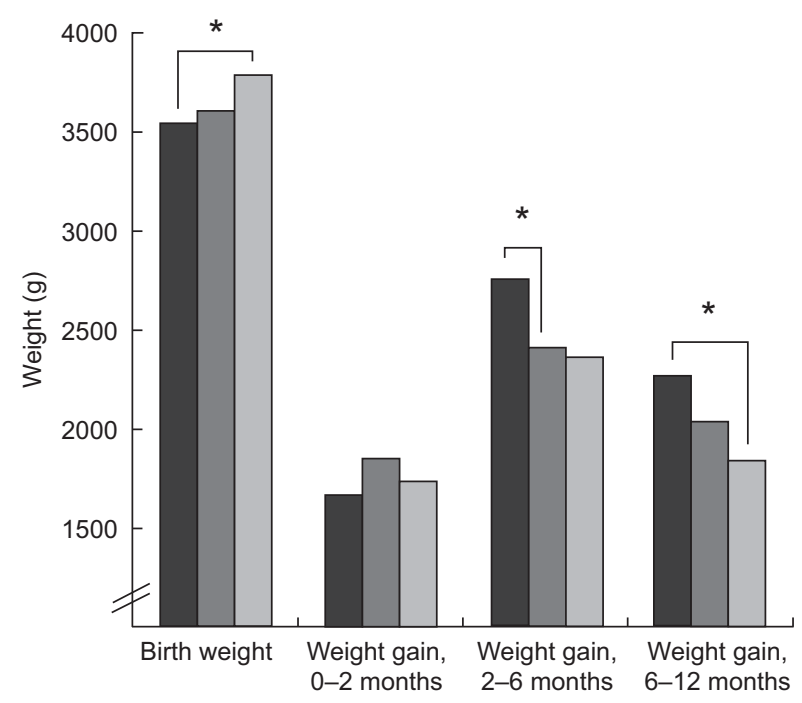

Fig. 1 Association between birth weight and weight gain during infancy and duration of exclusive breast-feeding (EBF; $\square$, $\leq 2$ months; $\square, 3-4$ months; $\square, \geq 5$ months) in two populations with a long duration of EBF from Denmark and Iceland ( $\left.{ }^{\star} P<0.01\right)$. Infants exclusively breast-fed for $\leq 2$ months gained $348(95 \% \mathrm{Cl} 69,626) \mathrm{g}$ more weight in the period $2-6$ months than those exclusively breast-fed for 3-4 months $(P=0.009)$. A difference in weight gain from 2 to 6 months between infants exclusively breast-fed for $\leq 2$ months compared with infants exclusively breast-fed for $\geq 5$ months $(389 \mathrm{~g} ; 95 \% \mathrm{Cl}$ $-20,798 \mathrm{~g})$ was of borderline significance $(P=0.068)$. Infants exclusively breast-fed for $\leq 2$ months also tended to gain 421 $(95 \% \mathrm{Cl} 85,756) \mathrm{g}$ more weight from 6 to 12 months of age than infants exclusively breast-fed for $\geq 5$ months $(P=0.008)$

Icelandic infants were heavier at birth and were exclusively breast-fed for a longer duration. Other associations seen between duration of EBF and weight or growth in infancy were not confounded by difference between cohorts. Infants exclusively breast-fed for $\leq 2$ months 
Table 2 Weight and weight gain in infancy in age- and gender-specific quartiles of childhood BMI: randomly selected healthy newborns from Denmark and Iceland followed up in childhood

\begin{tabular}{|c|c|c|c|c|c|c|c|c|c|c|c|c|c|}
\hline & \multicolumn{3}{|c|}{ Q1 } & \multicolumn{3}{|c|}{ Q2 } & \multicolumn{3}{|c|}{ Q3 } & \multicolumn{3}{|c|}{ Q4 } & \multirow[b]{2}{*}{$P$ for trend $t$} \\
\hline & $n$ & Mean & SD & $n$ & Mean & SD & $n$ & Mean & SD & $n$ & Mean & SD & \\
\hline \multicolumn{14}{|l|}{ Weight $(\mathrm{g})$} \\
\hline Birth & 46 & 3640 & 474 & 49 & 3711 & 450 & 46 & 3560 & 389 & 45 & 3563 & 403 & 0.245 \\
\hline Age 2 months & 28 & 5305 & 586 & 27 & 5514 & 562 & 30 & 5268 & 522 & 19 & 5208 & 716 & $0 \cdot 180$ \\
\hline Age 6 months & 32 & 7568 & 936 & 35 & 7984 & 896 & 38 & 7918 & 919 & 32 & 8259 & 905 & 0.043 \\
\hline Age 12 months & 28 & 9724 & 899 & 35 & 9929 & 983 & 34 & 9996 & 1141 & 23 & 10400 & 1370 & 0.062 \\
\hline \multicolumn{14}{|l|}{ Weight gain $(\mathrm{g})$} \\
\hline Birth to 2 months & 28 & 1709 & 451 & 27 & 1841 & 387 & 30 & 1797 & 430 & 19 & 1659 & 628 & 0.185 \\
\hline 2 to 6 months & 26 & 2156 & 624 & 27 & 2416 & 583 & 29 & 2617 & 543 & 19 & 2904 & 670 & 0.006 \\
\hline 6 to 12 months & 25 & 2115 & 613 & 32 & 1999 & 437 & 33 & 2068 & 598 & 23 & 2205 & 822 & 0.383 \\
\hline \multicolumn{14}{|l|}{ Breast-feeding } \\
\hline Exclusive (months) & 46 & $2 \cdot 8$ & 1.9 & 49 & $3 \cdot 0$ & $1 \cdot 7$ & 44 & $3 \cdot 1$ & $1 \cdot 6$ & 43 & $2 \cdot 9$ & $2 \cdot 1$ & 0.698 \\
\hline
\end{tabular}

tLogistic regression models estimating the risk of being in the highest age- and gender-specific quartile of childhood BMI, using the infant weight, infant weight gain and breast-feeding variables as continuous.

gained 348 (95\% CI 69, 626) g more weight in the period 2-6 months than those exclusively breast-fed for 3-4 months $(P=0 \cdot 009)$. A difference in weight gain from 2 to 6 months between infants exclusively breast-fed for $\leq 2$ months compared with infants exclusively breast-fed for $\geq 5$ months (389g; $95 \%$ CI $-20,798 \mathrm{~g}$ ) was of borderline significance $(P=0 \cdot 068)$. Infants exclusively breast-fed for $\leq 2$ months also tended to gain 421 (95\% CI $85,756) \mathrm{g}$ more weight from 6 to 12 months of age than infants exclusively breast-fed for $\geq 5$ months $(P=0 \cdot 008)$. A correlation was seen between the duration of EBF and total duration of partial breast-feeding $(r=0 \cdot 766$, $P<0 \cdot 001)$ which might partly explain the finding that EBF was related to growth in the second half of infancy. The average duration of partial breast-feeding was $7 \cdot 4$ (SD $3 \cdot 2)$ months in the Icelandic cohort and $6 \cdot 4$ (SD $4 \cdot 0)$ months in the Danish. At the age of 12 months, $13 \%$ and $19 \%$ of infants were still breast-fed in Iceland and Denmark, respectively.

\section{Follow-up}

The association between weight and weight gain during infancy and childhood BMI was assessed for age- and gender-specific quartiles. These results can be seen in Table 2, where the $P$ for trend is based on the continuous variable adjusted for country. The difference in weight gain velocity in infancy between the age- and genderspecific quartiles of childhood BMI is largest for the weight gain from 2 to 6 months of age. The difference in growth patterns during infancy between those in the lowest and highest childhood BMI quartile in Iceland and Denmark can be seen in Fig. $2 a$ and $2 b$.

Age- and gender-specific quartiles were used in our primary analysis but in order to explore the relationship between infant growth and childhood BMI further we created $Z$-scores based on the UK growth references ${ }^{(20)}$. Greater weight change in terms of $Z$-score from the age of 2 months to the age of 6 months was associated with higher $Z$-score of childhood BMI when adjusted for birth
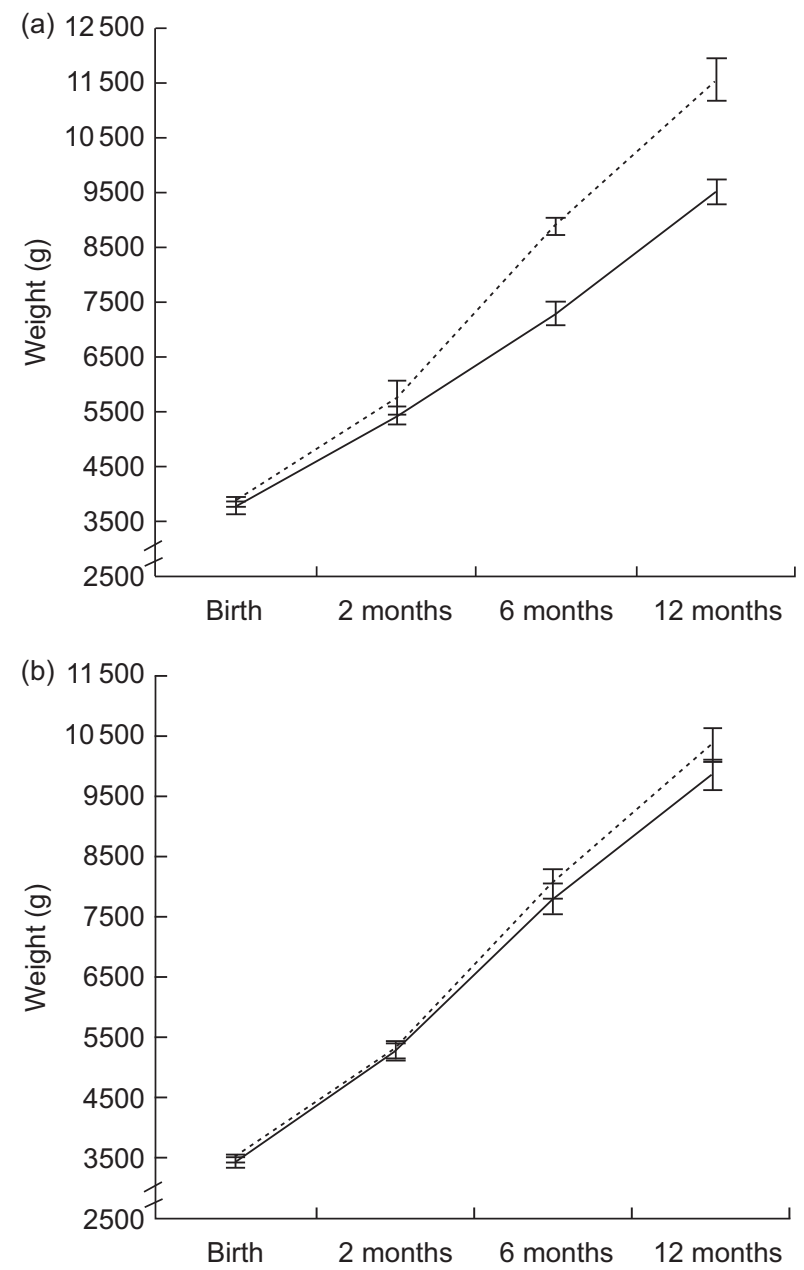

Fig. 2 Weight (with error bars representing $\mathrm{SE}$ ) at birth, 2 months, 6 months and 12 months for children in the lowest $(\mathrm{Q} 1,--)$ and highest $(\mathrm{Q} 4,---)$ quartile of BMI at (a) the age of 6 years in the Icelandic cohort and (b) the age of 10 years in the Danish cohort

weight, duration of exclusive breast-feeding and country $\left(B=0 \cdot 49\right.$, SE $=0 \cdot 11, \quad P<0 \cdot 001$, adj. $\left.R^{2}=0 \cdot 15\right)$. When analysing the cohorts separately the association was seen 
to be stronger in the Icelandic cohort, where the growth rate from 2 to 6 months was found to explain $40 \%$ of the variance in childhood BMI in the Icelandic model compared with $3 \%$ in the Danish one $(B=0 \cdot 69, \mathrm{sE}=0 \cdot 13$, $P<0 \cdot 001$, adj. $R^{2}=0 \cdot 40$, and $B=0 \cdot 37$, se $=0.17, P=$ $0 \cdot 035$, adj. $R^{2}=0 \cdot 03$, respectively). Those in the highest quartile of BMI in childhood tended to be shorter than the others at birth ( $P$ for trend $=0 \cdot 058$ ). Other measurements of length or length growth during infancy were not related to childhood BMI. Duration of EBF was not different between BMI categories in childhood, neither in Iceland nor Denmark.

\section{Discussion}

The current paper presents data from two Nordic countries which were part of the Nordic longitudinal epidemiological research programme, the NordNet Study. Due to the similarity of the studies involved, as well as the detailed information on growth and feeding in infancy, we had the opportunity to study the association between growth velocity during narrow periods in infancy and childhood BMI. The results show that EBF beyond 2 months of age is related to lower weight gain from 2 to 6 months as well as from 6 to 12 months of age, and the growth velocity in the period from 2 months to the age of 6 months is related to high childhood BMI. The results also show that there are important differences as well as similarities between Iceland and Denmark in growth patterns.

The association between growth velocity in infancy and childhood BMI was found to be stronger in Iceland than in Denmark. At the time of the Icelandic infant study, regular cow's milk was introduced very early or alongside breast-feeding during weaning and at the same time the use of infant formula was uncommon ${ }^{(6)}$. Regular cow's milk has considerably higher protein content than breast milk or infant formula, and thus the practice of introducing cow's milk to young infants therefore increases the intake of protein considerably. Dietary protein can stimulate growth, and it has been suggested that high protein intake in early life increases the risk of obesity. The proposed mechanism is that high protein intake stimulates the secretion of insulin-like growth factor I (IGF-I) and thereby protein synthesis and cell proliferation ${ }^{(21)}$. The increased IGF-I levels may then accelerate growth and increase muscle mass and adipose tissue ${ }^{(22)}$. Earlier analysis from the Icelandic cohorts revealed that high protein intake in late infancy was positively related to childhood overweight ${ }^{(12)}$, and in a recent study from Germany high protein intake during the period of complementary feeding was associated with an unfavourable body composition at the age of 7 years ${ }^{(23)}$. However, high intake of protein in infancy was not related to childhood overweight in the Danish infants ${ }^{(13)}$, which may be explained by a smaller range in protein intake as well as a relatively low intake of protein. In many of the studies where rapid growth in early infancy is being related to the development of childhood or adult overweight, information on the method of infant feeding has either been lacking $^{(2)}$ or recorded only in the very first days of life $\mathrm{f}^{(1,3)}$.

The emphasis on EBF has increased in recent years, with EBF for 6 months now being recommended ${ }^{(15)}$. In the present study EBF was not directly associated with childhood BMI, which could partly be explained by the relatively small sample size and therefore limitations in statistical power. However, EBF strongly influenced growth rate during infancy in the present study. It has been suggested that the lower BMI and lower risk of overweight among breast-fed children later in life is already achieved at 1 year of age ${ }^{(24)}$. Only very few studies have focused especially on duration of EBF in relation to childhood overweight ${ }^{(25,26)}$, but the total duration of breast-feeding in relation to risk of overweight has been studied more thoroughly. Two recent meta-analysis addressed this question and both suggested a protective effect of breast-feeding ${ }^{(11,27)}$, although the difference in BMI between breast-fed and formula-fed subjects was small $^{(27)}$. It might be suggested that the means of complementary feeding strongly influences the association between breast-feeding duration and later BMI, and some cultural differences in complementary feeding practices between countries might partly explain differences observed between different studies ${ }^{(28)}$.

A limitation of the present study is the different ages at follow-up and it cannot be excluded that some of the difference observed between the two cohorts in terms of how infant growth was related to childhood BMI is due to different ages at follow-up. However, strong tracking patterns of overweight were recently shown in an Icelandic cohort where about $72 \%$ of the children who were overweight at age 6 years were still overweight at the age of 9 years ${ }^{(29)}$. This suggests that even though the followup was not conducted at exactly the same age in the two cohorts, it is likely that we would had come to a similar conclusion if the Icelandic children had been assessed at the age of 10 years instead of 6 years.

The greatest differences in weight and growth patterns between Icelandic and Danish infants seem to be in prenatal growth. The comparison made in the current study shows that the average birth weight of the Icelandic infants was about $400 \mathrm{~g}$ higher than among the Danish infants. What causes this difference is unclear, but the almost universal use of cod-liver oil by the Icelandic population as well as high intake of protein, through intake of fish and milk during pregnancy, has been suggested $^{(30-32)}$. The meaning of this difference for health in later life has also been discussed, as low birth weight has been related to adult diseases in several studies and also in the high-birth-weight population of Iceland ${ }^{(30,31,33-35)}$. However, in recent studies high birth weight has in 
many cases been related to both childhood and adult overweight $^{(36-40)}$, that might be related to the increasing pre-pregnancy weight of mothers following the obesity epidemic. In the present study birth weight was not a predictor of childhood BMI.

In conclusion, although the duration of EBF was not associated with childhood BMI in the present study it may modulate growth rate in infancy, which is related to childhood BMI. However, other factors determinative for infant growth also need to be considered when assessing the relationship of early growth and nutrition to childhood overweight, as traditions in complementary food might differ between populations.

\section{Acknowledgements}

The collaboration upon which the present paper is based is part of the Nordic longitudinal epidemiologic research programme 'Prenatal and Childhood Growth in Relation to Cardiovascular Disease' (the NordNet Study) funded by NordForsk, the Nordic Research Board. The initial studies were supported by The Icelandic Centre for Research (The Icelandic Infant Study) and The Danish Research Councils and FÿTEK (The Danish Research and Development Programme for Food and Technology). The authors have no conflicts of interest. I.T. and K.F.M. were the scientists responsible for the infant cohorts. I.G. and L.S.-N. contributed to the data management and data analysis. I.G. wrote the first draft of the manuscript. All authors contributed to the NordForsk collaboration and interpretation of the results.

\section{References}

1. Stettler N, Zemel BS, Kumanyika S \& Stallings VA (2001) Infant weight gain and childhood overweight status in a multicenter cohort study. Pediatrics 109, 194-199.

2. Stettler N, Bovet P, Shamlaye H, Zemel BS, Stallings VA \& Paccaud F (2002) Prevalence and risk factors for overweight and obesity in children from Seychelles, a country in rapid transition: the importance of early growth. Int $J$ Obes Relat Metab Disord 26, 214-219.

3. Stettler N, Stallings VA, Troxel AB, Zhao J, Schinnar R, Nelson SE, Ziegler EE \& Strom BL (2005) Weight gain in the first week of life and overweight in adulthood. A cohort study of European American subjects fed infant formula. Circulation 111, 1897-1903.

4. Ong KK \& Loos RJ (2006) Rapid infancy weight gain and subsequent obesity: systematic reviews and hopeful suggestions. Acta Paediatr 95, 904-908.

5. Karaolis-Danckert N, Buyken AE, Bolzenius K, Perim de Faria C, Lentze MJ \& Kroke A (2006) Rapid growth among term children whose birth weight was appropriate for gestational age has a longer lasting effect on body fat percentage than on body mass index. Am J Clin Nutr 84, $1449-1455$.

6. Atladottir H \& Thorsdottir I (2000) Energy intake and growth of infants in Iceland - a population with high frequency of breast-feeding and high birth weight. Eur J Clin Nutr 54, 695-701.
7. Nielsen GA, Thomsen BL \& Michaelsen KF (1998) Influence of breastfeeding and complementary food on growth between 5 and 10 months. Acta Paediatr 87, 911-917.

8. Michaelsen KF, Petersen S, Greisen G \& Thomsen BL (1994) Weight, length, head circumference, and growth velocity in a longitudinal study of Danish infants. Dan Med Bull 41, $577-585$.

9. Gillman MW, Rifas-Shiman SL, Camargo CA, Berkey CS, Frazier AL, Rockett HR, Field AE \& Colditz GA (2001) Risk of overweight among adolescents who were breastfed as infants. JAMA 285, 2461-2467.

10. von Kries R, Koletzko B, Sauerwald T, von Mutius E, Barnert D, Grunert V \& von Voss H (1999) Breast feeding and obesity: cross sectional study. BMJ 319, 147-150.

11. Harder T, Bergmann R, Kallischnigg G \& Plagemann A (2005) Duration of breastfeeding and risk of overweight: a meta-analysis. Am J Epidemiol 162, 397-403.

12. Gunnarsdottir I \& Thorsdottir I (2003) Relationship between growth and feeding in infancy and body mass index at the age of 6 years. Int J Obes Relat Metab Disord 27, 1523-1527.

13. Hoppe C, Mølgaard C, Thomsen BL, Juul A \& Michaelsen KF (2004) Protein intake at 9 mo of age is associated with body size but not with body fat in 10-y-old Danish children. Am J Clin Nutr 79, 494-501.

14. Nordic Council of Ministers (2004) Nordic Nutrition Recommendations Integrating Nutrition and Physical Activity. Nord 2004:13. Copenhagen: Nordic Council of Ministers.

15. World Health Organization (2001) Global Strategy for Infant and Young Child Feeding, The Optimal Duration of Exclusive Breastfeeding. Geneva: WHO.

16. World Health Organization (2004) Promoting Proper Feeding of Infants and Children. Geneva: WHO.

17. Michaelsen KF (1997) Nutrition and growth during infancy. The Copenhagen Cohort Study. Acta Paediatr Suppl 420, $1-36$.

18. Freeman J, Cole TJ, Chinn S, Jones PRM, White EM \& Preece MA (1995) Cross-sectional stature and weight reference curves for the UK 1990. Arch Dis Child 73, $17-24$.

19. Cole TJ, Freeman JV \& Preece MA (1990) Body mass index reference curves for the UK. Arch Dis Child 73, 25-29.

20. Child Growth Foundation (1996) UK Cross-sectional Reference Data: 1990/1. London: Child Growth Foundation.

21. Rolland-Cachera MF, Deheeger M, Akrout M \& Bellisle F (1995) Influence of macronutrients on adiposity development: a follow up study of nutrition and growth from 10 months to 8 years of age. Int J Obes Relat Metab Disord 19 , 573-578.

22. Michaelsen KF (2000) Are there negative effects of an excessive protein intake? Pediatrics 106, 1293.

23. Günther AL, Buyken AE \& Kroke A (2007) Protein intake during the period of complementary feeding and early childhood and the association with body mass index and percentage body fat at 7 y of age. Am J Clin Nutr 85, 1626-1633.

24. Scholtens S, Gehring U, Brunekreef B, Smit HA, de Jongste JC, Kerkhof M, Gerritsen J \& Wijga AH (2007) Breastfeeding, weight gain in infancy, and overweight at seven years of age: the prevention and incidence of asthma and mite allergy birth cohort study. Am J Epidemiol 165, 919-926.

25. Weyermann M, Rothenbacher D \& Brenner H (2006) Duration of breastfeeding and risk of overweight in childhood: a prospective birth cohort study from Germany. Int J Obes (Lond) 30, 1281-1287.

26. Kalies H, Heinrich J, Borte N, Schaaf B, von Berg A, von Kries R, Wichmann HE, Bolte G \& LISA Study Groups 
(2005) The effect of breastfeeding on weight gain in infants: results of a birth cohort study. Eur J Med Res 10, 36-42.

27. Owen CG, Martin RM, Whincup PH, Davey-Smith G, Gillman MW \& Cook DG (2005) The effect of breastfeeding on mean body mass index throughout life: a quantitative review of published and unpublished observational evidence. Am J Clin Nutr 82, 1298-1307.

28. Karolis-Danckert N, Günther ALB, Hornberg C \& Buyken AE (2007) How early dietary factors modify the effect of rapid weight gain in infancy on subsequent body-composition development in term children whose birth weight was appropriate for gestational age. Am J Clin Nutr 86, 1700-1708.

29. Johannsson E, Arngrimsson SA, Thorsdottir I \& Sveinsson T (2006) Tracking of overweight from early childhood to adolescence in cohorts born 1988 and 1994: overweight in a high birth weight population. Int J Obes (Lond) 30, $1265-1271$.

30. Gunnarsdottir I, Birgisdottir BE, Thorsdottir I, Gudnason V \& Benediktsson R (2002) Size at birth and coronary artery disease in a population with high birth weight. Am J Clin Nutr 76, 1290-1294.

31. Birgisdottir BE, Gunnarsdottir I, Thorsdottir I, Gudnason V \& Benediktsson R (2002) Size at birth and glucose intolerance in a relatively genetically homogeneous, highbirth weight population. Am J Clin Nutr 76, 399-403.

32. Olsen SF, Halldorsson TI, Willett WC, Knudsen VK, Gillman MW, Mikkelsen TB, Olsen J \& NUTRIX Consortium (2007) Milk consumption during pregnancy is associated with increased infant size at birth: prospective cohort study. Am J Clin Nutr 86, 1104-1110.
33. Godfrey KM \& Barker DJ (2000) Fetal nutrition and adult disease. Am J Clin Nutr 71, 5 Suppl., 1344S-1352S.

34. Leon DA, Lithell HO, Vågerö D, Koupilová I, Mohsen R, Berglund L, Lithell UB \& McKeigue PM (1998) Reduced fetal growth rate and increased risk of death from ischaemic heart disease: cohort study of 15000 Swedish men and women born 1915-29. BMJ 317, 241-245.

35. Eriksson JG, Forsén T, Tuomilehto J, Osmond C \& Barker DJP (2001) Early growth and coronary heart disease in later life: longitudinal study. BMJ 322, 949-953.

36. Sørensen HT, Sabroe S, Rothman KJ, Gillman M, Fischer P \& Sørensen TI (1997) Relation between weight and length at birth and body mass index in young adulthood: cohort study. BMJ 315, 1137.

37. Eriksson J, Forsén T, Tuomilehto J, Osmond C \& Barker D (2001) Size at birth, childhood growth and obesity in adult life. Int J Obes Relat Metab Disord 25, 735-740.

38. Gunnarsdottir I, Birgisdottir BE, Benediktsson R, Gudnason V \& Thorsdottir I (2004) Association between size at birth, truncal fat and obesity in adult life and its contribution to blood pressure and coronary heart disease; study in a high birth weight population. Eur J Clin Nutr 58, 812-818.

39. Rugholm S, Baker JL, Olsen LW, Schack-Nielsen L, Bua J \& Sørensen TI (2005) Stability of the association between birth weight and childhood overweight during the development of the obesity epidemic. Obes Res 13, 2187-2194.

40. Rogers IS, Ness AR, Steer CD, Wells JC, Emmett PM, Reilly JR, Tobias J \& Smith GD (2006) Associations of size at birth and dual-energy X-ray absorptiometry measures of lean and fat mass at 9 to $10 \mathrm{y}$ of age. Am J Clin Nutr 84, 739-747. 